\title{
PERTANGGUNGJAWABAN PIDANA BAGI PELAKU KEJAHATAN PERDAGANGAN HASIL ILLEGAL LOGGING
}

\author{
Arlin Parlindungan Harahap \\ Fakultas Hukum, Universitas Muhammadiyah Sumatera Utara, Medan \\ arlinhararahap76@gmail.com
}

\begin{abstract}
Abstrak
Illegal logging merupakan kegiatan penebangan, pengangkutan, atau penjualan kayu yang tidak sah atau tidak memiliki izin dari otoritas setempat. Illegal logging dan perdagangan illegal menyebabkan kerusakan hutan, kerugian bagi Negara, serta dapat menyebabkan tata pemerintahan. Penelitian ini bertujuan untuk mengetahui untuk mengetahui unsur-unsur kesalahan dalam kejahatan tindak pidana perdagangan hasil illegal logging, untuk mengetahui proses penyidikan kepolisian dalam penanganan kejahatan perdagangan hasil illegal logging, untuk mengetahui petanggungjawaban pidana bagi pelaku kejahatan perdagangan hasil illegal logging. Bahwa Pertanggungjawaban pidana bagi pelaku kejahatan perdagangan hasil illegal logging ialah seseorang akan dipertanggungjawabkan atas tindakan kejahatan yang dilakukannya, yang mana tindakan tersebut merupakan perbuatan melawan hukum serta tidak ada alasan pembenar atau peniadaan sifat melawan hukum untuk pidana yang dilakukannya. Kemampuan bertanggung jawab, maka. perbuatan seseorang dikatakan telah melanggar hukum, dan dapat dikenakan sanksi pidana maka harus dipenuhi 2 (dua) unsur yakni adanya unsur perbuatan pidana (actrus reus) dan adanya niat jahat (mens rea). Dalam membebani pertanggungjawaban pidana terhadap pelaku kejahatan perdagangan hasil illegal logging harus terpenuhi syarat segala unsur-unsur kejahatan dan maksud dari tujuan perbuatan tersebut harus dapat dibuktikan bahwa memang sengaja diperbuat dengan kondisi sadar akan di langgarnya suatu perbuatan pidana yang diatur oleh suatu peraturan perundang-undangan.
\end{abstract}

Kata kunci: pertanggungjawaban, pidana, pelaku, illegal loging

\section{PENDAHULUAN}

Seiring dengan perkembangan kehidupan masyarakat modern dalam menghadapi globalisasi serta adanya proses industrialisasi dan modernisasi akan menumbuhkan perubahan proses sosial dalam tata kehidupan masyarakat. Proses industrialisasi dan modernisasi dan terutama industrialisasi kehutanan telah berdampak besar pada kelangsungan hutan sebagai penyangga hidup dan kehidupan mahluk didunia. Hutan merupakan sumber daya yang sangat penting tidak hanya sebagai sumber daya kayu, tetapi lebih sebagai salah satu komponen lingkungan hidup. ${ }^{1}$

Sejalan dengan Pasal 33 UndangUndang Dasar Republik Indonesia Tahun 1945 sebagai landasan konstitusional yang mewajibkan agar bumi, air dan kekayaan alam yang terkandung di dalamnya dikuasai oleh Negara dan dipergunakan sebesar-besarnya untuk kemakmuran rakyat, maka penyelenggaraan kehutanan senantiasa mengandung jiwa dan semangat kerakyatan, berkeadilan dan berkelanjutan. Oleh karena itu, penyelenggara kehutanan harus dilakukan dengan asas manfaat dan lestari, kerakyatan, keadilan, kebersamaan, keterbukaan dan

1 Siswanto Sunarso, Hukum Pidana Lingkungan Hidup dan Strategi penyelesaian sengketa, Rineka Cipta, Jakarta, 2005, hal 6 keterpaduan dengan dilandasi akhlak mulia dan bertanggung jawab. ${ }^{2}$

Hutan merupakan sumber daya alam yang terbuka, sehingga akses masyarakat untuk masuk memanfaatkannya sangat besar. Kondisi tersebut memacu permasalahan dalam pengelolaan hutan. Berbagai faktor penyebab timbulnya kerusakan hutan diantaranya dapat terjadi akibat perbuatan kesengajaan atau kelalaian subyek hukum yang terdiri dari manusia dan atau badan hukum, karena ternak dan daya-daya alam misalnya gempa bumi, letusan gunung, banjir dan sebagainya, dan juga dapat terjadi karena serangan hama dan penyakit pohon.

Di daerah-daerah hutan banyak ditemui kasus di mana orang, warga masyarakat atau suatu kelompok tertentu karena alasan ekonomi melakukan penebangan satu buah pohon kayu di hutan dengan tanpa ijin, ditangkap, ditahan dan didakwa telah melakukan tindak pidana illegal logging.

Kegiatan illegal loging yang dilakukan oleh perorangan maupun perusahaan seharusnya dapat dimintai pertanggungjawaban pidananya, karena telah merusak ekosistem serta membahayakan kehidupan manusia. Potensi-potensi bahaya dari kegiatan illegal iloging itu seharusnya mendapat perhatian yang cukup banyak dari aparat penegak hukum.

${ }^{2}$ Ibid. 


\section{METODE PENELITIAN}

\section{Illegal Loging dalam Perspektif Hukum} di Indonesia

Illegal Logging atau pembalakan illegal/liar merupakan kegiatan penebangan kayu secara tidak sah dengan melanggar peraturan perundang-undangan, yaitu berupa; pencurian kayu di dalam kawasan hutan negara atau hutan hak (milik) dan atau pemegang izin melakukan penebangan lebih dari jatah yang telah ditetapkan dalam perizinannya. Pembalakan ilegal juga terkait dengan masalah perdagangan ilegal atau penyelundupan kayu maupun produk kayu (kayu gergajian, plywood, dan sebagainya). ${ }^{3}$

Menurut Riza Suarga, mengemukakan bahwa illegal logging adalah sebagai suatu praktik eksploitasi hasil hutan berupa kayu dari kawasan hutan Negara melalui aktifitas penebangan pohon atau pemanfaatan dan peredaran kayu atau olahannya yang berasal dari hasil tebangan secara tidak sah. Kegiatan illegal logging ini meliputi kegiatan illegal processing dan illegal trade. ${ }^{4}$

Departemen Kehutanan menegaskan yang disebut illegal logging adalah tindak pidana penebangan pohon dengan aktifitasnya dengan mengacu pada Undang-Undang Republik Indonesia Nomor 41 Tahun 1999 tentang Kehutanan dan Peraturan Pemerintah Nomor 34 Tahun 2002 tentang Tata Hutan Dan Penyusunan Rencana Pengelolaan Hutan, Pemanfaatan Hutan dan Penggunaan Kawasan Hutan, meliputi; kegiatan menebang atau memanen hasil hutan di dalam kawasan hutan tanpa memiliki hak atau izin yang berwenang, serta menerima, memberi atau menjual, menerima tukar, menerima titipan, menyimpan, mengangkut, menguasai atau memiliki hasil hutan yang tidak dilengkapi dengan surat sahnya hasil hutan.

Pemerintah Indonesia dalam penanganan illegal logging telah dengan mengeluarkan berbagai peraturan perundangundangan, yaitu; Undang-Undang Nomor 18 Tahun 2013 Tentang Pencegahan dan Pemberantasan Perusakan Hutan, UndangUndang Nomor 41 Tahun 1999 tentang Kehutanan yang mencabut Undang-Undang Nomor 5 Tahun 1967 tentang Ketentuan-

${ }^{3}$ Ricar Zarof, Disparitas Pemidanaan Pembalakan Liar dan Pengaruhnya Terhadap Penegakan Hukum di Indonesia, P.T Alumni, Bandung, 2012, hlm. 142

${ }^{4}$ Riza Suarga, Pemberantasan Illegal Logging, Optimisme di Tengah Praktek Premanisme Global, Wana Aksara, Banten, 2005, hlm. 6
Ketentuan Pokok Kehutanan, Undang-Undang Nomor 5 Tahun 1990 tentang Konservasi Sumber Daya Alam Hayati dan Ekosistemnnya, Peraturan Pemerintah Nomor 45 Tahun 2004 tentang Perlindungan Hutan yang mencabut Peraturan Pemerintah Nomor 28 Tahun 1985 tentang Perlindungan Hutan, Peraturan Pemerintah Nomor 34 Tahun 2002 tentang Tata Hutan Dan Penyusunan Rencana Pengelolaan Hutan, Pemanfaatan Hutan dan Penggunaan Kawasan Hutan, Peraturan Pemerintah Republik Indonesia Nomor 45 Tahun 2004 tentang Perlindungan Hutan, serta dikeluarkannya Instruksi Presiden Nomor 4 Tahun 2005 tentang Pemberantasan Penebangan Kayu secara Illegal di Kawasan Hutan dan Peredarannya di Seluruh Wilayah Republik Indonesia.

Instruksi Presiden Nomor 4 Tahun 2005 tentang Pemberantasan Penebangan Kayu secara Illegal di Kawasan Hutan dan Peredarannya di Seluruh Wilayah Republik Indonesia, menginstruksikan kepada seluruh pejabat pemerintah Negara Republik Indonesia untuk melakukan percepatan pemberantasan illegal logging di seluruh wilayah dan setiap daerah negara Indonesia.

Dengan lahirnya berbagai regulasi di atas tetap saja tidak menyurutkan langkah para pelaku kejahatan perambahan hutan secara illegal untuk tetap secara legal merambah hutan di Indonesia. Pembalakan liar, pencurian kayu dan pengelolaan hasil hutan tanpa izin merupakan kasus yang sering atau biasa didengar karena tingkat terjadinya kejahatan di bidang kehutanan sering terjadi di Indonesia. Kejahatan illegal logging tersebut, apabila dibiarkan secara terus menerus akan berdampak pada rusaknya hutan yang tentu dapat merugikan negara dan bahkan membahayakan kelangsungan hidup manusia dan makhluk hidup lainnya.

Banyak kasus-kasus illegal logging yang telah terjadi disetiap kawasan-kawasan hutan lindung di negara Indonesia. Khususnya kondisi hutan di Sumatera Utara yang semakin memprihatinkan. Pemerintah pusat dan daerah diminta memberi perhatian penuh untuk menghindari kemungkinan terjadinya bencana akibat rusaknya hutan dikarenakan penebangan hutan yang sudah tidak terkendali. Apabila kegiatan illegal logging di kawasan hutan di daerah propinsi Sumatera Utara terus-menerus dilakukan maka akan menimbulkan dampak kerugian ekonomi yang sangat besar bagi negara. Kerusakan hutan tersebut juga akan mengakibatkan timbul bencana alam, seperti; banjir, tanah longsor, dan sebagainya akan sulit untuk dihindari.

Beberapa sejumlah kasus-kasus yang pernah terjadi diseluruh wilayah hutan propinsi 
Sumatera Utara, berdasarkan rekap data di Kepolisian Negara Republik Indonesia Daerah Sumatera Utara Direktorat Reserse Kriminal Khusus periode tahun 2016 sampai 2018 bahwa telah terjadi sebanyak 20 kasus tindak pidana illegal logging yang terjadi. Laporan kasuskasus tindak pidana illegal loging yang terjadi di daerah-daerah propinsi Sumatera Utara beradasarkan data pada Diskreskrimsus dan Satwil Sejajaran Polda Sumut bahwa laporan tindak pidana iilegal logging di Polres Tanah Karo sebanyak 5 kasus, Polres Tobasa sebanyak 2 kasus, Polres Tapanuli Selatan sebanyak 9 kasus, Polres Tapanuli Tengah sebanyak 1 kasus, Polres Labuhan Batu 1 kasus, Polres, Sibolga 2 kasus. ${ }^{5}$

Illegal logging merupakan suatu kegiatan yang dilakukan pembalakan liar, pencurian kayu, dan pengelolaan hasil hutan tanpa izin, sebagaimana kasus illegal logging yang terjadi disalah satunya wilayah dikawasan hutan Indonesia di lokasi dalam kawasan hutan lindung terletak di Desa/Nagiru Sipangan Bolon, Kecamatan Girsang Sipangan Bolon, Kabupaten Simalungun, Propinsi Sumatera Utara. $^{6}$

\section{HASIL PENELITIAN dan PEMBAHASAN \\ Bentuk Pertanggungjawaban Tindak Pidana Perdagangan Hasil Illegal Logging \\ Pertanggungjawaban merupakan suatu} prinsip yang mendasar di dalam hukum pidana, atau yang lebih sering dikenal sebagai asas "geen straf zonder schuld" (tiada pidana tanpa kesalahan). Tetapi, apabila pertanggungjawaban pidana tanpa adanya kesalahan dalam diri si pelaku tindak pidana maka disebut dengan leer van het materiele feit. Sedangkan dalam KUHP sendiri tidak memberikan sebuah penjelasan mengenai apa yang dimaksud dengan asas "geen straf zonder schuld", akan tetapi asas ini dapat dikatakan sebagai asas yang tidak tertulis dan berlaku di Indonesia. Oleh karena itu, dalam sebuah pertanggungjawaban pidana terdapat dua hal yang harus diperhatikan, yakni;

5 Kepolisian Negara Republik Indonesia Daerah Sumatera Utara Direktorat Reserse Kriminal Khusus, Rekap Data Tindak Pidana Illegal Logging Pada Ditreskrimsus Dan Satwil Sejajaran Polda Sumut Tahun 20162018.

6 Berkas Perkara Kepolisian Negara Republik Indonesia Daerah Sumatera Utara Direktorat Reserse Kriminal Khusus, Nomor: BP/ /IV/2018/Dtreskrimsus tindak pidana (daad strafrecht), pelaku tindak pidana (dader straftrecht). ${ }^{7}$

Pelaku tindak pidana dapat dipidana apabila memenuhi syarat bahwa tindak pidana yang dilakukannya memenuhi unsur-unsur yang telah ditentukan dalam undang-undang. Dilihat dari sudut terjadinya tindakan yang dilarang, seseorang akan dipertanggungjawabkan atas tindakan-tindakan tersebut, apabila tindakan tersebut melawan hukum serta tidak ada alasan pembenar atau peniadaan sifat melawan hukum untuk pidana yang dilakukannya. Kemampuan bertanggung jawab maka hanya seseorang yang mampu bertanggung jawab yang dapat dipertanggungjawabkan atas perbuatanya, sebagaimana hal dipidananya seseorang yang melakukan perbuatan seperti melawan hukum.

Pembuat (dader) harus ada unsur kesalahan dan bersalah yang harus memenuhi unsur, yaitu: ${ }^{8}$

1) Kemampuan bertanggung jawab atau dapatnya dipertanggungjawabkan dari si pembuat.

2) Adanya kaitan psikis antara pembuat dan perbuatan, yaitu adanya sengaja atau kesalahan (culpa). Pelaku mempunyai kesadaran yang mana pelaku seharusnya dapat mengetahui akan adanya akibat yang ditimbulkan dari perbuatannya.

3) Tidak adanya dasar peniadaan pidana yang menghapus dapatnya dipertanggungjawabkan sesuatu perbuatan kepada pembuat.

Asas legalitas hukum pidana Indonesia yang diatur dalam Pasal 1 ayat (1) Kitab Undang-undang Hukum Pidana (KUHP) dimaksudkan bahwa seseorang baru dapat dikatakan melakukan perbuatan pidana apabila perbuatannya tersebut telah sesuai dengan rumusan dalam undang-undang hukum pidana. Meskipun orang tersebut belum tentu dapat dijatuhi hukum pidana, karena masih harus dibuktikan kesalahannya apakah dapat dipertanggungjawabkan pertanggung jawaban tersebut. Agar seseorang dapat dijatuhi pidana, harus memenuhi unsur-unsur perbuatan pidana dan pertanggungjawaban pidana.

Menurut Ruslan Saleh, ${ }^{9}$ tidaklah ada gunanya untuk mempertanggungjawabkan

7 Roni Wiyanto, Asas-asas Hukum Pidana Indonesia, Mandar Maju, Bandung, 2012, hal 96.

8 Andi Hamzah, Asas-Asas Hukum

Pidana, Rineka Cipta, Jakarta, 1997, hlm. 130

${ }^{9}$ Ruslan Saleh., Perbuatan Pidana dan Pertanggungjawaban Pidana, Aksara Baru, Jakarta, 1999, hlm. 75 
terdakwa atas perbuatannya apabila perbuatannya itu sendiri tidak bersifat melawan hukum, maka lebih lanjut dapat pula dikatakan bahwa terlebih dahulu harus ada kepastian tentang adanya perbuatan pidana, dan kemudian semua unsur-unsur kesalahan harus dihubungkan pula dengan perbuatan pidana yang dilakukan, sehingga untuk adanya kesalahan yang mengakibatkan dipidanannya terdakwa maka terdakwa haruslah:

a) Melakukan perbuatan pidana;

b) Mampu bertanggung jawab;

c) Dengan kesengajaan atau kealpaan, dan

d) Tidak adanya alasan pemaaf.

Seorang pembuat dalam melakukan suatu tindak pidana dalam menentukan adanya pertanggungjawaban harus ada sifat melawan hukum dari tindak pidana yang merupakan sifat terpenting dari tindak pidana. Sifat melawan hukum dihubungkan dengan keadaan psikis (jiwa) pembuat terhadap tindak pidana yang dilakukannya dapat berupa kesengajaan (opzet) atau karena kelalaian (culpa).

Suatu perbuatan dikatakan telah melanggar hukum, dan dapat dikenakan sanksi pidana maka harus dipenuhi 2 (dua) unsur yakni adanya unsur perbuatan pidana (actrus reus) dan adanya niat jahat (mens rea). Kesalahan (schuld) merupakan unsur pembuat delik, jadi termasuk unsur pertanggungjawaban pidana yang mana terkandung makna dapat dicelanya si pembuat atas perbuatannya. Dalam hal kesalahan tidak terbukti, berarti bahwa perbuatan pidana (actus reus) sebenarnya tidak terbukti, karena tidak mungkin hakim akan membuktikan adanya kesalahan jika ia telah mengetahui lebih dahulu bahwa perbuatan pidana tidak ada atau tidak terbukti diwujudkan oleh terdakwa. ${ }^{10}$

Seseorang dikatakan mampu bertanggungjawab apabila memenuhi 3 (tiga) syarat, yaitu: ${ }^{11}$

1. Dapat menginsyafi makna daripada perbuatannya.

2. Dapat menginsyafi bahwa perbuatannya itu tidak dapat dipandang patut dalam pergaulan masyarakat.

3. Mampu untuk menentukan niat atau kehendak dalam melakukan perbuatan.

Ada beberapa alasan seseorang tidak dapat bertanggung jawab atas tindak pidana yang dilakukan, yaitu: ${ }^{12}$

10 Andi Zainal Abidin, Asas-Asas Hukum Pidana Bagian Pertama. Alumni, Bandung, 1987, hlm. 72

${ }^{11}$ Roeslan Saleh, Op. Cit., hlm. 80 a. Jiwa si pelaku cacat.

b. Tekanan jiwa yang tidak dapat ditahan.

c. Gangguan penyakit jiwa

Seseorang tersebut belum tentu dapat dijatuhi hukum pidana, karena masih harus dibuktikan kesalahannya apakah dapat dipertanggungjawabkan pertanggungjawaban pidana. Agar seseorang dapat dijatuhi pidana, harus memenuhi unsur-unsur perbuatan pidana dan pembuktiannya.

Dalam

membebani pertanggungjawaban pidana terhadap pelaku kejahatan perdagangan hasil illegal logging harus terpenuhi syarat segala unsur-unsur kejahatan dan maksud dari tujuan perbuatan tersebut harus dapat dibuktikan bahwa memang sengaja diperbuat dengan kondisi sadar akan di langgarnya perbuatan tersebut yang diatur oleh suatu peraturan perundang-undangan.

Sudarto dalam bukunya, bahwa agar seseorang memiliki aspek pertanggungjawaban pidana dalam arti dipidananya pebuat terdapat beberapa syarat yang harus dipenuhi, yaitu: ${ }^{13}$

a. Adanya suatu tindak pidana yang dilakukan oleh pembuat.

b. Adanya unsur kesalahan berupa kesengajaan atau kealpaan.

c. Adanya pembaut yang mampu bertanggung jawab.

d. Tidak ada alasan pemaaf.

Berbagai perumusan tindak pidana illegal logging dalam UU No. 18 Tahun 2018, tercantum unsur sengaja atau kealpaan/kelalaian maka dapat dikatakan bahwa pertanggungjawaban pidana dalam tindak pidana kejahatan perdagangan hasil illegal logging menganut prinsip liability based on fault (pertanggungjawaban berdasarkan kesalahan).

Prinsipnya menganut asas kesalahan atau culpabilitas, maka didalam pertanggungjawaban pidana seolah-olah tidak dimungkinkan adanya pertanggungjawaban mutlak (strict liability atau "absolute liability). Secara teoritis sebenarnya dimungkinkan adanya penyimpangan terhadap asas kesalahan dengan menggunakan prinsip/ajaran strict liability atau vicorius liability. Dimana ajaran ini lebih menitik beratkan pada actus reus (perbuatan yang dilarang) tanpa

${ }^{12}$ Leden Mapaung, Asas-Teori-Praktik Hukum Pidana, Sinar Grafrika, Jakarta, 2005, hal 72

${ }^{13}$ Hanafi Amrani, Mahrus Ali, Sistem Pertanggungjawabaan pidana, perkembangan dan penerapan, Rajawali Pers, Jakarta, 2015, hlm. 22 
mempertimbangkan adanya mens rea (kesalahan).

Pertanggungjawaban pidana pada hakikatnya mengandung makna pencelaan pembuat (subjek hukum) atas tindak pidana yang telah dilakukannya. Oleh karena itu, pertanggung jawaban pidana mengandung di dalamnya pencelaan atau pertanggungjawaban objektif dan subjektif. Artinya, secara objektif si pembuat telah melakukan tindak pidana menurut hukum yang berlaku (asas legalitas) dan secara subjektif si pembuat patut dicela atau dipersalahkan/ dipertanggungjawabkan atas tindak pidana yang dilakukan baik berupa kesengajaan ataupun kealpaan (asas culpabilitas/kesalahan) sehingga ia patut dipidana.

Bentuk pertanggungjawaban pidana terhadap pelaku kejahatan perdagangan hasil illegal logging hanya dapat dikenakan memakai Pasal 12 huruf (d) dan (m) jo. Pasal 83 ayat (1) huruf a dan Pasal 87 ayat (1) UU No. 18 Tahun 2013 tentang Pencegahan dan Pemberantasan Perusakkan Hutan.

Pasal 12 huruf (d) UU No. 18 Tahun 2013 tentang Pencegahan dan Pemberantasan Perusakkan Hutan, menyatakan bahwa "memuat, membongkar, mengeluarkan, mengangkut, menguasai, dan/atau memiliki hasil penebangan di kawasan hutan tanpa izin."

Pasal 12 huruf (m) UU No. 18 Tahun 2013 tentang Pencegahan dan Pemberantasan Perusakkan Hutan, menyatakan bahwa "menerima, menjual, menerima tukar, menerima titipan, menyimpan, dan/atau memiliki hasil hutan kayu yang berasal dari kawasan hutan yang diambil atau dipungut secara tidak sah."

Pasal 83 ayat (1) huruf (a) UU No. 18 Tahun 2013 tentang Pencegahan dan Pemberantasan Perusakkan Hutan, menyatakan bahwa "memuat, membongkar, mengeluarkan, mengangkut, menguasai, dan/atau memiliki hasil penebangan di kawasan hutan tanpa izin sebagaimana dimaksud dalam Pasal 12 huruf d; dipidana dengan pidana penjara paling singkat 1 (satu) tahun dan paling lama 5 (lima) tahun serta pidana denda paling sedikit Rp. 500.000.000,00 (lima ratus juta rupiah) dan paling banyak Rp. 2.500.000.000,00 (dua miliar lima ratus juta rupiah)." Unsur-unsur yang terdapat pada pasal ini, yaitu: ${ }^{14}$

1) Setiap orang dilarang

14 Kepolisian Negara Republik Indonesia Daerah Sumatera Utara Direktorat reserse Kriminal Khusus, Berkas Perkara Nomor:BP/ /IV/2018/Ditreskrimsus
Yang dimaksud dengan setiap orang dilarang, yaitu subjek hukum, yakni:

a) Manusia

b) Badan hukum

2) Memuat, membongkar, mengeluarkan mengangkut, menguasai, dan/atau memiliki hasil penebangan di kawasan hutan

3) Tanpa izin

Sesuai Pasal 12 huruf d UU No. 18 Tahun 2013 tentang Pencegahan dan Pemberantasan Perusakkan Hutan bahwa setiap orang dilarang memuat, membongkar, mengeluarkan, mengangkut, menguasai dan/atau memiliki hasil penebangan dikawasan hutan tanpa izin.

Yang dimaksud dengan "memuat" adalah memasukkan ke dalam alat angkut, sebagaimana disebut dalam Penjelasan Pasal 12 huruf d UU No. 18 Tahun 2013.

Adapun dokumen yang digunakan sebagai legalitas dari memuat, membongkar, mengeluarkan, mengangkut, menguasai dan/atau memiliki hasil penebangan dikawasan hutan dengan fungsi kawasan hutan lindung dengan terlebih dahulu memperoleh izin dari Kementerian Lingkungan Hidup dan Kehutanan, antara lain: Izin Pinjam Pakai Kawasan Hutan (IPPKH) yang melakukan pemanfaatan kayu bulat dari kawasan hutan adalah Dokumen SKSHHK (surat Keterangan Sahnya Hasil Hutan Kayu). ${ }^{15}$

Pasal 87 ayat (1) huruf (c) UU No. 18 Tahun 2013 tentang Pencegahan dan Pemberantasan Perusakkan Hutan, menyatakan bahwa "orang perseorangan yang dengan sengaja menerima, menjual, menerima tukar, menerima titipan, menyimpan, dan/atau memiliki hasil hutan kayu yang berasal dari kawasan hutan yang diambil atau dipungut secara tidak sah sebagaimana dimaksud dalam Pasal 12 huruf $\mathrm{m}$, dipidana dengan pidana penjara paling singkat 1 (satu) tahun dan paling lama 5 (lima) tahun dan pidana denda paling sedikit Rp500.000.000,00 (lima ratus juta rupiah) dan paling banyak Rp2.500.000.000,00 (dua miliar lima ratus juta rupiah). Unsur-unsur yang terdapat pada pasal ini, yaitu: ${ }^{16}$

1) Setiap orang dilarang

Yang dimaksud dengan setiap orang dilarang, yaitu subjek hukum, yakni:
a) Manusia
b) Badan hukum

2) Menerima, menjual, menerima tukar, menerima titipan, menyimpan, dan/atau memiliki hasil hutan kayu yang berasal dari kawasan hutan

\footnotetext{
15 Ibid.

${ }^{16}$ Ibid.
} 
3) Yang diambil atau dipungut secara di sah Adapun dokumen yang digunakan sebagai legalitas dari memuat, membongkar, mengeluarkan, mengangkut, menguasai dan/atau memiliki hasil penebangan dikawasan hutan dengan fungsi kawasan hutan lindung dengan terlebih dahulu memperoleh izin dari Kementerian Lingkungan Hidup dan Kehutanan, antara lain: Izin Pinjam Pakai Kawasan Hutan (IPPKH) yang melakukan pemanfaatan kayu bulat dari kawasan hutan adalah Dokumen SKSHHK (Surat Keterangan Sahnya Hasil Hutan Kayu). ${ }^{17}$

Didalam UU No. 18 Tahun 2013 Tentang Pencegahan dan Pemberantasan Kerusakan hutan, juga tergambarkan mengenai unsur-unsur pertanggungjawaban pidana yang terdapat didalam Pasal 12. Adapun unsur-unsur pertanggungjawaban pidana secara umum didalam Hukum Pidana Indonesia adalah:

1. Kemampuan bertanggungjawab

2. Kesalahan (Dolus dan Culpa)

Berdasarkan unsu-unsur yang tersebut diatas, bahwa mengenai bentuk pertanggungjawaban pidana bagi pelaku kejahatan hasil illegal logging dalam Pasal 12 huruf (d) dan (m) jo. Pasal 83 ayat (1) huruf a dan Pasal 87 ayat (1) UU No. 18 Tahun 2013 tentang Pencegahan dan Pemberantasan Perusakkan Hutan, yaitu:

1. Menyebutkan unsur kesalahan berupa kesengajaan

2. ancaman pidana atau sanksi pidana kepada pelaku yaitu ancaman pidana penjara paling singkat 1 (satu) tahun dan paling lama 5 (lima) tahun serta pidana denda paling sedikit Rp500.000.000,00 (lima ratus juta rupiah) dan paling banyak Rp2.500.000.000,00 (dua miliar lima ratus juta rupiah).

Membuktian kesalahan seseorang yang melakukan pidana kejahatan perdagangan hasil illegal logging sebagaimana dikenakan pada pelaku, yaitu Pasal 12 huruf (d) dan (m) jo. Pasal 83 ayat (1) huruf a dan Pasal 87 ayat (1) UU No. 18 Tahun 2013 tentang Pencegahan dan Pemberantasan Perusakkan Hutan ialah pembuktian yang sebagaimana diatur dalam Pasal 184 KUHAP yang menyatakan bahwa "alat bukti yang sah ialah: ${ }^{18}$
a. keterangan saksi
b. keterangan ahli;
c. surat;

\footnotetext{
${ }^{17}$ Ibid.

18 Pasal 184 ayat (1), Kitab UndangUndang Hukum Acara Pidana
}

d. petunjuk;

e. keterangan terdakwa."

Pembuktian merupakan hal yang memegang perann penting dalam proses perkara, karena pembuktian merupakan syarat yang harus terpenuhi dalam penyelesaian perkara. Penentuan mengenai cara bagaimana pengenaan pembuktian pidana dapat dilaksanakan terhadap orang yang disangka melakukan perbuatan pidana, yang diatur dalam hukum pidana formal atau KUHAP. ${ }^{19}$

Pembuktian tentang benar tidaknya terdakwa melakukan perbuatan yang didakwakan, merupakan bagian yang terpenting acara pidana.dalam hal ini pun hak asasi manusia dipertaruhkan. Bagaimana akibatnya jika seseorang yang didakwa dinyatakan terbukti melakukan perbuatan yang didakwakan berdasarkan alat bukti yang ada disertai dengan keyakinan hakim, padahal tidak benar. Untuk inilah hukum acara pidana bertujuan mencari kebenaran materil. ${ }^{20}$

Berdasarkan pembuktianlah ditentukan nasib dari terdakwa. Dimana hasil pembuktian dengan alat-alat bukti yang ditentukan undangundang "tidak cukup" membuktikan kesalahan yang didakwakan kepada terdakwa maka terdakwa "dibebaskan" dari hukuman. Sebaliknya, jikalau kesalahan terdakwa dapat dibuktikan dengan alat-alat bukti yang cukup maka terdakwa dapat dinyatakan "bersalah", dan kepadanya akan dijatuhi hukuman. ${ }^{21}$

Proses pembuktian atau membuktikan mengandung maksud dan usaha untuk menyatakan kebenaran atas sesuatu peristiwa, sehingga dapat diterima akal terhadap kebenaran peristiwa tersebut. Pembuktian mengandung arti bahwa benar suatu peristiwa pidana telah terjadi dan terdakwalah yang bersalah melakukannya, sehingga harus mempertanggungjawabkannya. ${ }^{22}$

Pembuktian adalah ketentuanketentuan yang berisi penggarisan dan pedoman

19 Andi Hamzah, Mohammad Taufik Makarao, dan Suhasril, Hukum Acara Pidana dalam Teori dan Praktek, Ghalia, Jakarta, 2004, hlm. 2

${ }^{20}$ Andi Hamzah, Hukum Acara Pidana Indonesia, CV. Sapta Artha Jaya, Jakarta, 1996, hlm.257

21 M. Yahya Harahap, Pembahasan Permasalahan Penerapan KUHAP: Pemeriksaan Sidang Pengadilan, Banding, Kasasi, dan Peninjauan Kembali, Sinar Grafika, Jakarta, 2000, hlm. 273.

22 Darwan Prinst, Hukum Acara Pidana Dalam Praktik, Djambatan, Jakarta, 1998, hlm. 133 
tentang cara-cara yang dibenarkan undangundang membuktikan kesalahan yang didakwakan kepada terdakwa. Pembuktian juga merupakan ketentuan yang mengatur alat-alat bukti yang dibenarkan undang-undang dan boleh dipergunakan hakim membuktikan kesalahan yang didakwakan. ${ }^{23}$

Hukum pembuktian merupakan sebagian dart hukum acara pidana yang mengatur macam-macam alat bukti yang sah menurut hukum, sistem yang dianut dalam pembuktian, syarat-syarat dan tata cara mengajukan bukti tersebut serta kewenangan hakim untuk menerima, menolak dan menilai suatu pembuktian. ${ }^{24}$

Kitab Undang-Undang Hukum Acara Pidana tidak memberikan penjelasan mengenai pengertian pembuktian. KUHAP hanya memuat peran pembuktian dalam Pasal 183 bahwa hakim tidak boleh menjatuhkan pidana kepada seseorang kecuali apabila dengan sekurangkurangnya dua alat bukti yang sah ia memperoleh keyakinan bahwa suatu tindak pidana benar-benar terjadi dan bahwa terdakwalah yang bersalah melakukannya.

Penyidik Kepolisian Polda Sumatera Utara telah melakukan penyitaan terhadap barang milik pelaku kejahatan perdagangan hasil illegal logging untuk dijadikan sebagai bukti atas tindak pidana pidana yang telah dilakukan oleh pelaku, yaitu berupa:

a. 1 (satu) unit mobil dump truck Mitsubishi type FE 349 warna kuning No. Polisi BK $8257 \mathrm{TE}$

b. 65 (enam puluh lima) batang kayu bulat jenis Eucalyptus.

\section{SIMPULAN}

Pertanggungjawaban pidana bagi pelaku kejahatan perdagangan hasil illegal logging ialah seseorang akan dipertanggungjawabkan atas tindakan kejahatan yang dilakukannya, yang mana tindakan tersebut merupakan perbuatan melawan hukum serta tidak ada alasan pembenar atau peniadaan sifat melawan hukum untuk pidana yang dilakukannya. Kemampuan bertanggung jawab, maka. perbuatan seseorang dikatakan telah melanggar hukum, dan dapat dikenakan sanksi pidana maka harus dipenuhi 2 (dua) unsur yakni

23 M.Yahya Harahap, Pembahasan Permasalahan dan Penerapan KUHAP: Pemeriksaan Sidang Pengadilan, Banding, Kasasi, dan Peninjauan Kembali, Sinar Grafika, Jakarta, 2006, hlm. 273

24 Hari Sasangka dan Lily Rosita, Hukum Pembuktian Dalam Perkara Pidana, Mandar Maju, Bandung, 2003, hlm. 10 adanya unsur perbuatan pidana (actrus reus) dan adanya niat jahat (mens rea). Dalam membebani pertanggungjawaban pidana terhadap pelaku kejahatan perdagangan hasil illegal logging harus terpenuhi syarat segala unsur-unsur kejahatan dan maksud dari tujuan perbuatan tersebut harus dapat dibuktikan bahwa memang sengaja diperbuat dengan kondisi sadar akan di langgarnya suatu perbuatan pidana yang diatur oleh suatu peraturan perundang-undangan.

\section{DAFTAR PUSTAKA}

Andi Hamzah, 1996, Hukum Acara Pidana Indonesia, CV. Sapta Artha Jaya, Jakarta.

1997, Asas-Asas Hukum Pidana, Rineka Cipta, Jakarta.

Andi Hamzah, Mohammad Taufik Makarao, dan Suhasril, 2002, Hukum Acara Pidana dalam Teori dan Praktek, Ghalia, Jakarta.

Andi Zainal Abidin, 1987, Asas-Asas Hukum Pidana Bagian Pertama. Alumni, Bandung.

Berkas Perkara Kepolisian Negara Republik Indonesia Daerah Sumatera Utara Direktorat Reserse Kriminal Khusus, Nomor: BP/ /IV/2018/Dtreskrimsus.

Darwan Prinst, 1998, Hukum Acara Pidana Dalam Praktik, Djambatan, Jakarta.

Hanafi Amrani, Mahrus Ali, 2015, Sistem Pertanggungjawabaan pidana, perkembangan dan penerapan, Rajawali Pers, Jakarta.

Harahap, M. Yahya, 2000, Pembahasan Permasalahan Penerapan KUHAP: Pemeriksaan Sidang Pengadilan, Banding, Kasasi, dan Peninjauan Kembali, Sinar Grafika, Jakarta.

M.Yahya, 2006, Pembahasan Permasalahan dan Penerapan KUHAP: Pemeriksaan Sidang Pengadilan, Banding, Kasasi, dan Peninjauan Kembali, Sinar Grafika, Jakarta.

Hari Sasangka dan Lily Rosita, 2003, Hukum Pembuktian Dalam Perkara Pidana, Mandar Maju, Bandung.

Kepolisian Negara Republik Indonesia Daerah Sumatera Utara Direktorat Reserse Kriminal Khusus, Rekap Data Tindak Pidana Illegal Logging Pada Ditreskrimsus Dan Satwil Sejajaran Polda Sumut Tahun 2016-2018.

Kepolisian Negara Republik Indonesia Daerah Sumatera Utara Direktorat reserse Kriminal Khusus, Berkas Perkara Nomor:BP/ /IV/2018/Ditreskrimsus. 
Marpaung, Leden, 2005, Asas-Teori-Praktik Hukum Pidana, Sinar Grafrika, Jakarta.

Ricar Zarof, 2012, Disparitas Pemidanaan Pembalakan Liar dan Pengaruhnya Terhadap Penegakan Hukum di Indonesia, P.T Alumni, Bandung.

Riza Suarga, 2005, Pemberantasan Illegal Logging, Optimisme di Tengah Praktek Premanisme Global, Wana Aksara, Banten.

Roni Wiyanto, 2010, Asas-asas Hukum Pidana Indonesia, Mandar Maju, Bandung.

Ruslan Saleh, 1999, Perbuatan Pidana dan Pertanggungjawaban Pidana, Aksara Baru, Jakarta.

Siswanto Sunarso, 2005, Hukum Pidana Lingkungan Hidup dan Strategi penyelesaian sengketa, Rineka Cipta, Jakarta.

Peraturan Perundang-undangan

Undang-undang Dasar Republik Indonesia Tahun 1945

Kitab Undang-undang Hukum Acara Pidana

Kitab Undang-undang Hukum Pidana

Undang-Undang Republik Indonesia Nomor 18 Tahun 2013 Tentang Pencegahan dan Pemberantasan Perusakan Hutan,

Undang-Undang Republik Indonesia Nomor 41 Tahun 1999 tentang Kehutanan, yang mencabut Undang-Undang Republik
Indonesia Nomor 5 Tahun 1967 tentang Ketentuan-Ketentuan Pokok Kehutanan,

Undang-Undang Republik Indonesia Nomor 5 Tahun 1990 tentang Konservasi Sumber Daya Alam Hayati dan Ekosistemnnya,

Peraturan Pemerintah Republik Indonesia Nomor 45 Tahun 2004 tentang Perlindungan Hutan, yang mencabut Peraturan Pemerintah Republik Indonesia Nomor 28 Tahun 1985 tentang Perlindungan Hutan,

Peraturan Pemerintah Republik Indonesia Nomor 34 Tahun 2002 tentang Tata Hutan Dan Penyusunan Rencana Pengelolaan Hutan, Pemanfaatan Hutan dan Penggunaan Kawasan Hutan,

Peraturan Pemerintah Republik Indonesia Nomor 45 Tahun 2004 tentang Perlindungan Hutan,

Instruksi Presiden Republik Indonesia Nomor 4 Tahun 2005 tentang Pemberantasan Penebangan Kayu secara Illegal di Kawasan Hutan dan Peredarannya di Seluruh Wilayah Republik Indonesia.

Berkas Perkara Kepolisisan Negara Repbulik Indonesia Daerah Sumatera Utara Direktorat Reserse Kriminal Khusus, No. BP / /IV/2018/Ditreskrimsus 